\title{
Analisis Kemampuan Berpikir Kreatif Siswa Ditinjau dari Motivasi Siswa pada Materi Lingkaran Di SMP Negeri 12 Singkawang
}

\author{
Dewi Ratna Sari ${ }^{1}$, Nurhayati ${ }^{2}$, Buyung ${ }^{3}$ \\ Pendidikan Matematika, STKIP Singkawang, Singkawang, Indonesia

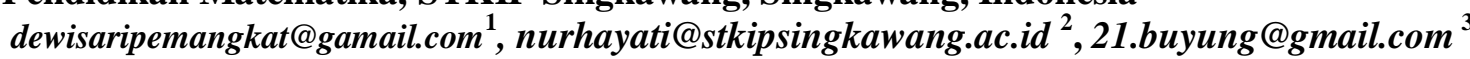

\section{Keywords :}

Kemampuan Berpikir Kreatif, Motivasi, Lingkaran
ABSTRACT
Penelitian ini bertujuan untuk mendeskripsikan kemampuan berpikir kreatif siswa ditinjau dari motivasi siswa serta untuk mengetahui faktor-faktor yang mempengaruhi kemampuan berpikir kreatif siswa di SMP Negeri 12 Singkawang. Jenis penelitian yang digunakan adalah penelitian deskriptif kualitatif. Subjek dalam penelitian ini adalah siswa kelas VIII A dengan jumlah 22 siswa. Pengambilan data menggunakan instrument berupa angket motivasi dan tes kemampuan berpikir kreatif. Adapun hasil penelitian: 1). (a). Siswa yang memiliki motivasi tinggi: kemampuan berpikir kreatif tinggi dapat memberikan ide yang relevan dalam penyelesaian pemecahan masalah matematika, kemampuan berpikir sedang dapat memberikan ide yang relevan meskipun pengungkapan yang diberikan kurang jelas, kemampuan berpikir kreatif rendah terdapat jawaban siswa untuk menuliskan rumus dengan kalimat yang singkat sehingga dalam mengungkapkan ide-idenya. (b). Siswa yang memiliki motivasi sedang: kemampuan berpikir kreatif tinggi terdapat siswa mengungkapkan ide-idenya dengan cara menyelesaikan soal yang diberikan kurang jelas, kemampuan berpikir kreatif sedang terdapat siswa kurang percaya diri dengan hasil jawaban sendiri, kemampuan berpikir kreatif rendah terdapat siswa memberikan ide yang relevan dalam penyelesaian pemecahan masalah matematika dengan benar dan lancar. (c). Siswa yang memiliki motivasi rendah: kemampuan berpikir kreatif tinggi terdapat tidak ada siswa yang memiliki motivasi rendah dan kemampuan berpikir kreatif tinggi, kemampuan berpikir kreatif sedang terdapat siswa memberikan ide yang relevan dalam penyelesaian matematika dengan benar dan lancar, kemampuan berpikir kreatif rendah terdapat siswa tidak sampai membuat kesimpulan karena sudah beranggapan hasil jawaban sudah benar. 2). (a). Faktor ketidakmampuan siswa mencapai tahap kemampuan berpikir kreatif matematika disebabkan siswa mengalami ketidakmampuan dalam mengungkapkan ide-idenya yang dimiliki untuk menyelesaikan soal yang diberikan. (b). Siswa kurang 


\begin{abstract}
percaya diri dengan hasil jawaban sendiri. (c). Siswa tidak mampu menentukan rumus yang akan digunakan. (d). Siswa sering menganggap pengecekan jawaban tidak penting karena beranggapan hasil jawaban sudah benar.
\end{abstract}

\title{
INTRODUCTION
}

Matematika mempunyai arti penting dalam membantu manusia menyelesaikan masalah pada kehidupan sehari-hari. Konsep-konsep pada ilmu matematika dapat diterapkan untuk memecahkan masalah yang sedang dihadapi. Tetapi juga membuat siswa lebih memahami konsep pada ilmu matematika itu sendiri dan membuat siswa lebih mengenal permasalahan-permasalahan dalam kehidupan sehari-hari yang dapat dipecahkan dengan pengetahuan matematika yang diperoleh siswa disekolah (Buyung, Resy Nirawati 2018: 21).

Dalam pembelajaran Matematika, idealnya siswa dibiasakan untuk memperoleh pemahaman melalui pengalaman dan pengetahuannya yang dikembangkan oleh siswa sesuai dengan perkembangan berpikirnya. Matematika sebagai wahana pendidikan memegang peran penting dalam pendidikan (Nindy Citroresmi P, Nurhayati 2017: 13). Dalam mengajarkan matematika, pembelajaran di kelas hampir selalu dilaksanakan secara konvensional. Akibatnya,siswa pada umumnya dapat melakukan berbagai perhitungan matematis, tetapi kurang menunjukkan hasil yang menggembirakan terkait penerapannya dalam kehidupan sehari-hari khususnya kemampuan komunikasi matematis Nurhayati, Sugiatno, \& Hamdani (2013: 2). Matematika merupakan salah satu sarana berpikir ilmiah dan logis serta mempunyai peran penting dalam upaya meningkatkan kualitas sumber daya manusia (Irwan 2011: 1) kemampuan-kemampuan tersebut dapat dikembangkan dalam pembelajaran matematika karena matematika memiliki struktur dan keterkaitan yang kuat dan jelas antar konsepnya sehingga memungkinkan siswa terampil berpikir rasional.

Menurut Undang-Undang No. 23 Tahun 2006 tentang Sistem Pendidikan Nasional (Sisdiknas) yaitu untuk mengembangkan kemampuan dan membentuk watak serta peradaban bangsa yang bermartabat dalam rangka mencerdaskan kehidupan bangsa.

Selain itu kemampuan berpikir kreatif merupakan keterampilan yang dapat dipelajari. Serta berpikir kreatif adalah suatu proses berpikir yang menghasilakan bermacam-macam kemungkinan ide dan cara secara luas dan beragam Tomi (2012: 23). Sehingga kemampuan berpikir kreatif adalah kemampuan untuk menghasilkan gagasan atau jawaban yang berdasarkan informasi yang sudah ada sebelumnya terhadap masalah matematika Yenni (2017: 337). Faktor yang mempengaruhi belajar dan prestasi belajar untuk mencapai kemampuan berpikir kreatif dapat digolongkan menjadi dua bagian, yaitu faktor internal dan faktor eksternal. Hal ini sejalan dengan pendapat (Siswono 2015: 16) berpikir kreatif merupakan suatu kebiasaan dari pemikiran yang tajam dengan intuisi, menggerakkan imajinasi.

Sejalan dengan hal tersebut peneliti juga melakukan pra observasi dan wawancara terhadap guru mata pelajaran di SMP Negeri 12 Singkawang, dengan pembelajaran Kurikulum Tingkat Satuan Pendidikan (KTSP) dengan demikian, kurikulum dapat memenuhi tuntutan waktu dan keadaan dalam membantu siswa menuju kebudayaan masa depan. Untuk memenuhi peranan tersebut, kurikulum perlu dikembangkan sesuai dengan perkembangan zaman, perkembangan teori dan praktek pendidikan (Nurul Husna, Nurhayati). Diperoleh informasi bahwa masih terdapat beberapa hal yang menyebabkan masih kurang optimalnya pembelajaran matematika khususnya pada materi lingkaran di SMP Negeri 12 Singkawang, rata-rata nilai siswa pada materi lingkaran termasuk rendah. Hal ini diperkuat dengan hasil ulangan harian siswa materi lingkaran tahun ajaran 2017/2018 di SMP Negeri 12 Singkawang. 
Hal ini dapat dilihat dari nilai ketuntasan belajar siswa pada sebelum materi lingkaran yaitu materi teorema Pythagoras. Kriteria Ketuntasan Minimal (KKM) yang ditentukan oleh sekolah pada pelajaran matematika adalah 75 . Siswa yang tuntas belajar hanya mencapai $40 \%$ dari jumlah siswa. Sedangkan siswa yang tidak tuntas belajar mencapai $60 \%$ dari jumlah siswa. Materi teorema Pythagoras dianggap sulit oleh siswa. Hal ini didukung oleh hasil prariset yang penulis lakukan di SMP Negri 12 Singkawang. Sebagai informasi awal penulis memberikan soal yang mengandung satu dari indikator kemampuan berpikir kreatif materi teorema Pythagoras yaitu berpikir lancar kepada 21 siswa kelas VIII.

Hasil analisis dari prariset yang diberikan kepada 20 siswa kelas VIII SMP Negeri 12 Singkawang diperoleh pada soal nomor satu dengan indikator menyatakan berpikir lancar, siswa yang menjawab salah sebesar 50\% dan yang menjawab benar hanya sebesar 50\% dari 20 siswa dan untuk soal nomor 2 dengan indikator yang sama siswa yang menjawab salah sebesar $85 \%$ dan siswa yang menjawab benar sebesar 15\% dari 20 siswa. Berdasarkan hasil prariset pada SMP Negeri 12 Singkawang tersebut, maka dapat diketahui bahwa rendahnya kemampuan berpikir kreatif pada indikator menyatakan tidak lancar menuliskan langkah-langkah penyelesaian soal.

Selain rendahnya kemampuan berpikir kreatif siswa dalam menyelesaikan soal matematika, motivasi juga mempunyai peran yang penting dalam menyelesaikan soal matematika. Karena motivasi merupakan dorongan yang timbul pada diri seseoran. Ladeni (2012: 83). menyatakan bahwa motivasi belajar adalah proses yang memberi semangat belajar, arah, dan kegigihan perilaku Sumartono (2015: 86). Hal ini sejalan dengan pendapat Uno (2016: 10) di mana indikator yang diukur yaitu memiliki hasrat atau keinginan untuk melakukan kegiatan, memiliki dorongan kebutuhan melakukan kegiatan, adanya harapan dan cita-cita, penghargaan dan penghormatan atas diri, adanya lingkungan yang baik, dan adanya kegiatan belajar yang menarik.

Sejalan dengan hal tersebut diperoleh bahwa masih terdapat beberapa hal yang menyebabkan masih kurang optimalnya pembelajaran matematika di SMP Negeri 12 Singkawang. Materi yang dipilih dalam penelitian ini adalah materi lingkaran khususnya pada submateri unsur dan bagian lingkaran serta keliling dan luas lingkaran.

Dari beberapa permasalahan di atas menunjukkan bahwa begitu pentingnya berpikir kreatif dalam pembelajaran matematika, sehingga penulis tertarik untuk mengungkap lebih jauh mengenai kemampuan berpikir kreatif matematis siswa ditinjau dari motivasi dalam menyelesaikan soal pada materi lingkaran melalui suatu penelitian. Karena tujuan dari berpikir kreatif adalah untuk mencapai pemahaman yang mendalam. Sehingga pendidik dan siswa dapat melaksanakan pembelajaran yang sesuai dengan tujuan pendidikan nasional.

\section{METHOD}

Jenis penelitian yang dilakukan merupakan jenis penelitian deskriptif dengan pendekatan kualitatif. Tujuannya adalah untuk mencari informasi serta mendeskripsikan kemampuan berpikir kreatif siswa ditinjau dari motivasi siswa, dan faktor yang mempengaruhi kemampuan berpikir kreatif siswa ditinjau dari motivasi siswa pada materi lingkaran siswa kelas VIII SMP Negeri 12 Singkawang.

Teknik pengumpulan data dalam penelitian ini adalah teknik pengukuran dan teknik komunikasi langsung. Teknik pengukuran adalah suatu alat berupa tes yang digunakan untuk mengukur ada atau tidaknya serta besar kemampuan objek yang diteliti Arikunto (2013: 266). Sedangkan teknik komunikasi langsung yang digunakan dalam penelitian ini yaitu melalui wawancara (interview). wawancara adalah proses memperoleh keterangan/data untuk tujuan penelitian dengan cara tanya jawab, sambil bertatap muka antara pewawancara dengan responden dengan menggunakan alat yang dinamakan panduan wawancara Siregar (2013: 18). Untuk tes kemampuan berpikir kreatif terdapat 3 
soal, angket motivasi terdapat 30 soal, teknik wawancara. Instrumen pengumpul data dalam penelitian ini yaitu: (a) tes kemampuan berpikir kreatif, (b) tes angket motivasi, dan lembar wawancara.

Teknik analisis data dalam penelitian ini adalah sebagai berikut: (a) untuk menjawab sub masalah 1, yaitu mengetahui kemampuan berpikir kreatif siswa ditinjau dari motivasi siswa pada materi lingkaran di SMP Negeri 12 Singkawang, maka menggunakan independent t-tes;

Tabel I menyajikan deskripsi kategori dari tiap-tiap persentase yaitu sebagai berikut:

Tabel 1. Deskripsi kategori dari tiap-tiap persentase

\begin{tabular}{rc}
\hline Retang Skor & Kriteria \\
\hline $70 \%<\mathrm{N} \leq 100 \%$ & Tinggi \\
$50 \%<\mathrm{N} \leq 70 \%$ & Sedang \\
$\mathrm{N} \leq 50 \%$ & Rendah
\end{tabular}

(b) untuk menjawab sub masalah 2, yaitu untuk mengetahui faktor-faktor yang mempengaruhi kemampuan berpikir kreatif siswa ditinjau dari motivasi siswa pada materi lingkaran di SMP Negeri 12 Singkawang maka skor ditentukan dengan rata-rata ideal $\left(M_{i}\right)$ dan standar deviasi ideal $\left(S d_{i}\right)$.

\section{RESULTS AND DISCUSSIONS}

Hasil penelitian ini diperoleh dari beberapa data yang telah dianalisis. Adapun hasil yang diperoleh dari penelitian ini yaitu, mengenai deskripsi kemampuan berpikir kreatif siswa ditinjau dari motivasi siswa, dan faktor-faktor yang mempengaruhi kemampuan berpikir kreatif siswa ditinjau dari motivasi siswa.

1.Hasil deskripsi kemampuan berpikir kreatif siswa ditinjau dari motivasi siswa

Setelah penelitian dilaksanakan, diperoleh data berupa hasil pekerjaan siswa kemudian dari data mentah tersebut diolah sehingga dapat dilihat pencapaian kemampuan berpikir kreatif siswa. Adapun hasil yang dicapai siswa sebagai berikut. Berdasarkan jawaban siswa yang diperoleh dapat diketahui bahwa siswa menjawab soal kemampuan berpikir kreatif dengan berbagai jawaban berbeda. Dari hasil jawaban siswa, kebanyakan hanya menjawab soal dengan cara yang singkat tetapi menghasilakan jawaban yang benar dan ada juga jawaban yang salah dalam penyelesaian masalah matematika. Dari hasil jawaban siswa untuk mengetahui kemampuan berpikir lancar, maka diambil 6 siswa sebagai subjek penelitian. Dari 6 siswa tersebut diambil 2 siswa kemampuan berpikir kreatif tinggi, 2 siswa kemampuan berpikir kreatif sedang dan 2 siswa kemampuan berpikir kreatif rendah. Adapun subjek yang dilakukan adalah S-12 (subjek 1), S-19 (subjek 2), S-4 (subjek 3), S-5 (subjek 4), S-9 (subjek 5), S-18 (subjek 6). Dari pencapaian tersebut siswa dikategorikan hanya dapat memberikan sebuah ide yang relevan dengan pemecahan masalah dan pengungkapan lengkap dan jelas.

Selesai pelaksanaan tes peneliti mengoreksi dan menganalisis hasil tes angket motivasi siswa. Hasil tes angket motivasi siswa ini untuk mengetahui apakah siswa tersebut dalam mempelajari materi lingkaran mempunyai motivasi tinggi, motivasi sedang, atau motivasi rendah. Sebelum peneliti mengklasifikasikan hasil tes angket motivasi siswa, peneliti akan menjelaskan cara untuk mengetahui apakah siswa tersebut dalam mempelajari materi lingkaran mempunyai motivasi tinggi, motivasi sedang, atau motivasi rendah.Tes angket motivasi siswa dalam mempelajari lingkaran terdapat 30 pernyataan yang harus dijawab oleh siswa. Dari ke 30 pernyataan tersebut terdapat dua kategori pernyataan, yaitu sebagai berikut:

a. Pernyataan positif, yaitu nomor 1, 2, 3, 4, 7, 8, 9, 10, 13, 14, 15, 16, 17, 20, 21, 22, 25, 26, 27, 28.

b. Pernyataan negatif, yaitu nomor 5, 6, 11, 12, 18, 19, 23, 24, 29, 30 .

Setiap pernyataan ini, terdapat lima pilihan jawaban yang harus dipilih oleh siswa. Lima pilihan jawaban itu diantaranya sangat setuju, setuju, kurang setuju, tidak setuju, dan sangat tidak setuju. Untuk penskorannya tergantung dari kategori pernyataannya. Untuk pernyataan positif sangat setuju skornya 4 , setuju skornya 3 , kurang setuju skornya 2 , tidak setuju skornya 1 , dan sangat tidak setuju 
skornya 0 . Sedangkan untuk pernyataan negatif sangat setuju skornya 0 , setuju skornya 1 , kurang setuju skornya 2, tidak setuju skornya 3 , dan sangat tidak setuju skornya 4.

Adapun hasil tes angket motivasi siswa kelas VIII A dalam mempelajari materi lingkaran adalah sebagai berikut, yaitu kategori tinggi, kategori sedang, dan kategori rendah. Adapun subjek kategori tinggi adalah subjek S-12 dan subjek S-19, subjek kategori sedang adalah subjek S-4 dan subjek S-5, subjek kategori rendah adalah subjek S-9 dan subjek S-18.

a. Deskripsi hasil kerja subjek S-12 ditinjau dari motivasi tinggi

Data hasil kerja subjek S-12 dalam menyelesaikan aspek berpikir lancar (Fluency)

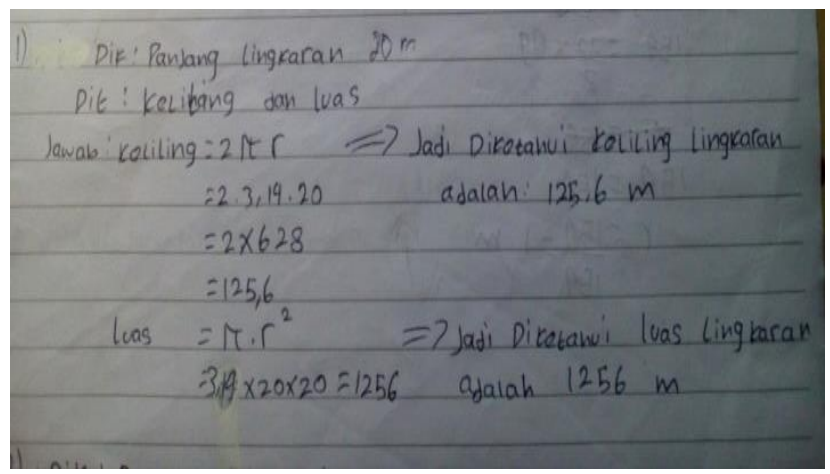

Gambar 1. Hasil Pekerjan subjek S-12

Berdasarkan hasil pekerjaan subjek S-12 pada aspek berpikir lancar (Fluency), terdapat jawaban siswa dengan menulis diketahui dan ditanya dengan kalimat yang singkat sehingga dalam mengungkapkan ide-idenya dengan cara menyelesaikan soal yang diberikan kurang jelas, walaupun menuliskan rumus keliling lingkaran dan luas lingkaran itu benar. Terdapat jawaban subjek S-12 hanya menjawab keliling lingkaran dengan menggunakan rumus $2 \times \pi \times \mathrm{r}$ dengan jawaban 125,6 $\mathrm{m}$ dan luas lingkaran dengan menggunakan rumus $\pi \times \mathrm{r}^{2}$ dengan jawaban $1.256 \mathrm{~m}$. Subjek dapat memberikan ide yang relevan dalam penyelesaian pemecahan masalah meskipun pengungkapan yang diberikan kurang jelas.

b. Deskripsi hasil kerja subjek S-19 ditinjau dari motivasi tinggi

Data hasil kerja subjek S-19 dalam menyelesaikan aspek berpikir lancar (Fluency)

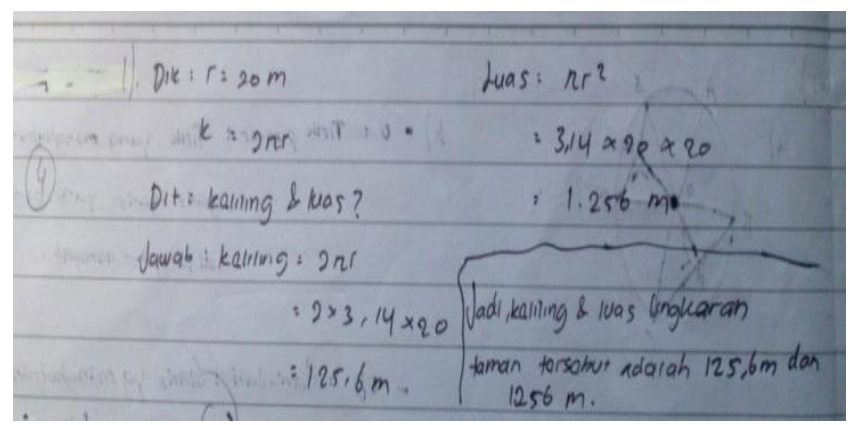

Gambar 2. Hasil Pekerjan subjek S-19 
Berdasarkan hasil pekerjaan subjek S-19 pada aspek berpikir lancar (Fluency), terdapat jawaban subjek dengan menulis diketahui dan ditanya dengan kalimat yang singkat sehingga dalam mengungkapkan ide-idenya dengan cara menyelesaikan soal yang diberikan kurang jelas, walaupun menuliskan rumus keliling lingkaran dan luas lingkaran itu benar. Terdapat jawaban subjek hanya menjawab keliling lingkaran dengan menggunakan rumus $2 \times \pi \times \mathrm{r}$ dengan jawaban 125,5 $\mathrm{m}$ dan luas lingkaran dengan menggunakan rumus $\pi \times \mathrm{r}^{2}$ dengan jawaban $1.256 \mathrm{~m}$. Subjek dapat memberikan ide yang relevan dalam penyelesaian pemecahan masalah matematika dengan benar dan lancar meskipun pengungkapan yang diberikan kurang jelas.

c. Deskripsi hasil kerja subjek S-4 ditinjau dari motivasi sedang

Data hasil kerja subjek S-4 dalam menyelesaikan aspek berpikir lancar (Fluency)

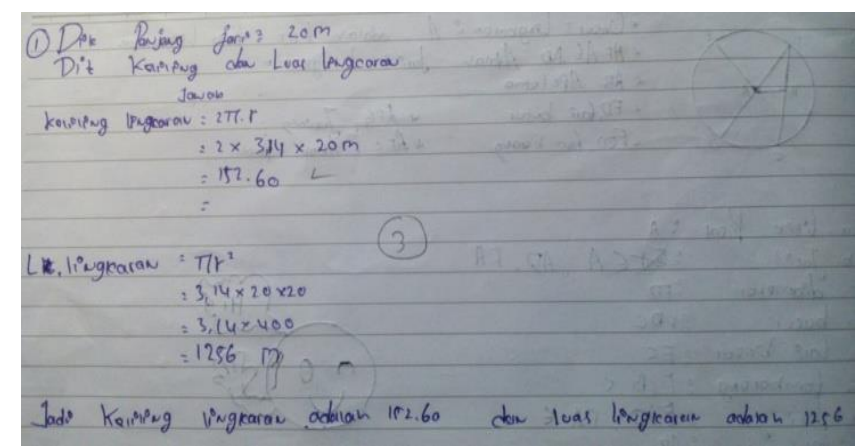

Gambar 3. Hasil Pekerjan subjek S-4

Berdasarkan hasil pekerjaan subjek S-4 diatas pada aspek berpikir lancar (Fluency), terdapat jawaban subjek dengan menulis diketahui dan ditanya dengan kalimat yang singkat sehingga dalam mengungkapkan ide-idenya dengan cara menyelesaikan soal yang diberikan kurang jelas, walaupun menuliskan rumus keliling lingkaran dan luas lingkaran itu benar. Terdapat jawaban subjek hanya menjawab keliling lingkaran dengan menggunakan rumus $2 \times \pi \times \mathrm{r}$ dengan jawaban 125, 60 dengan jawaban salah dan luas lingkaran dengan menggunakan rumus $\pi \times \mathrm{r}^{2}$ dengan jawaban $1.256 \mathrm{~m}$. Subjek kurang percaya diri dengan hasil jawaban sendiri tetapi dapat memberikan ide yang relevan

d. Deskripsi hasil kerja subjek S-5 ditinjau dari motivasi sedang

Data hasil kerja subjek S-5 dalam menyelesaikan aspek berpikir lancar (Fluency)

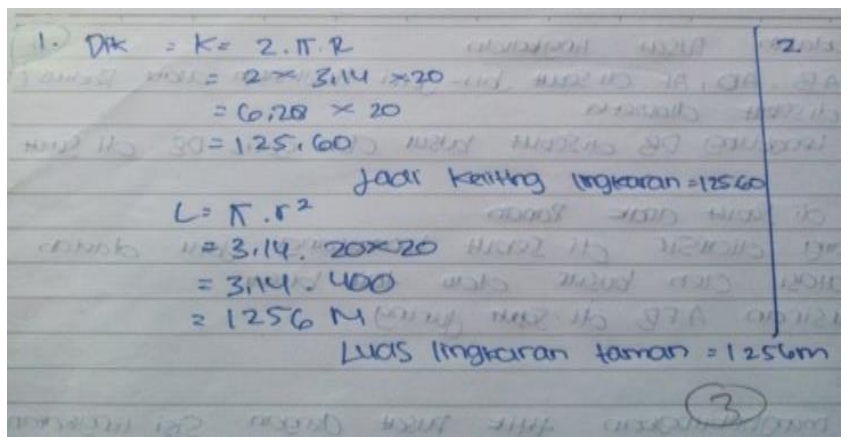

Gambar 4. Hasil Pekerjan subjek S-5

Berdasarkan hasil pekerjaan subjek S-5 diatas pada aspek berpikir lancar (Fluency), subjek dapat memberikan ide yang relevan dalam penyelesaian pemecahan masalah matematika dengan benar dan lancar meskipun pengungkapan yang diberikan kurang jelas

Kesimpulan kemampuan berpikir kreatif ditinjau dari motivasi sedang: 
Siswa yang memiliki motivasi sedang: kemampuan berpikir kreatif tinggi terdapat siswa mengungkapkan ide-idenya dengan cara menyelesaikan soal yang diberikan kurang jelas walaupun menuliskan rumus sudah benar.

e. Deskripsi hasil kerja subjek S-9 ditinjau dari motivasi rendah

Data hasil kerja subjek S-9 dalam menyelesaikan aspek berpikir lancar (Fluency)

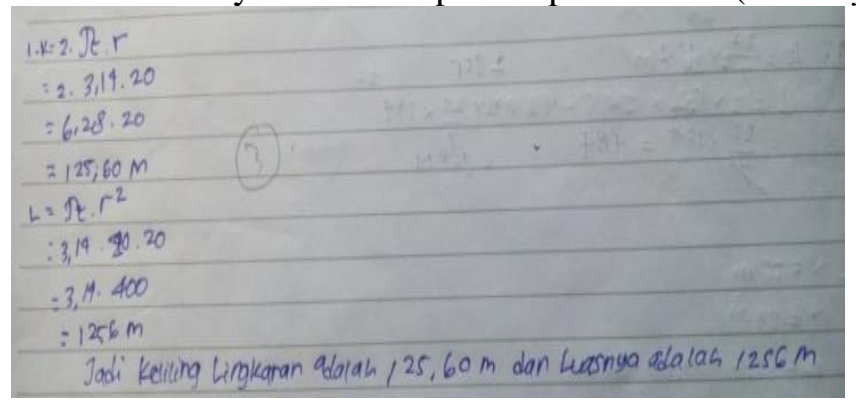

Gambar 5. Hasil Pekerjan subjek S-9

Berdasarkan hasil pekerjaan subjek S-9 diatas pada aspek berpikir lancar (Fluency) berdasarkan motivasi rendah, terdapat jawaban siswa dengan menulis diketahui dan ditanya dengan kalimat yang singkat sehingga tidak mampu dalam mengunggkapkan ide-idenya yang dimiliki dengan cara menyelesaikan soal yang diberikan, terdapat jawaban subjek S-9 hanya menjawab keliling lingkaran dengan menggunakan rumus $2 \times \pi \times \mathrm{r}$ dengan jawaban $1256 \mathrm{~m}$ dan luas lingkaran dengan menggunakan rumus $\pi \times \mathrm{r}^{2}$ dengan jawaban $1256 \mathrm{~m}$, tidak sampai kesimpulan meskipun pengungkapan yang diberikan kurang jelas.

f. Deskripsi hasil kerja subjek S-18 ditinjau dari motivasi rendah

Data hasil kerja subjek S-18 dalam menyelesaikan aspek berpikir lancar (Fluency)

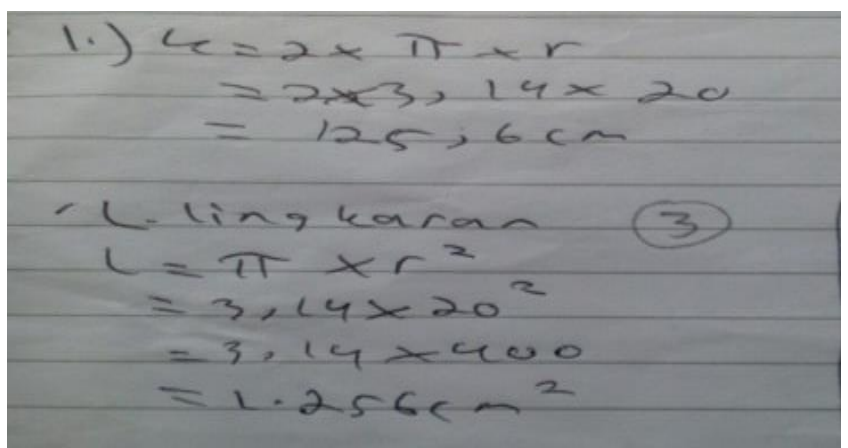

Gambar 6. Hasil Pekerjan subjek S-18

Berdasarkan hasil pekerjaan subjek S-18 diatas pada aspek berpikir lancar (Fluency) berdasarka motivasi rendah, terdapat jawaban subjek S-18 hanya menjawab keliling lingkaran dengan menggunakan rumus $\pi \mathrm{x}$ d dengan jawaban $125,5 \mathrm{~cm}$ dan luas lingkaran dengan menggunakan rumus $\pi \times \mathrm{r}^{2}$ dengan jawaban $1.256 \mathrm{~m}^{2}$ tidak sampai kesimpulan karena subjek tersebut sudah menganggap pengecekan jawaban tidak penting dan beranggapan hasil jawaban sudah benar.

Setelah penelitian dilaksanakan, diperoleh data berupa hasil pekerjaan siswa kemudian dari data mentah tersebut diolah sehingga dapat dilihat pencapaian kemampuan berpikir kreatif siswa. Kemudian peneliti mengelompokan kemampuan berpikir kreatif matematika siswa tinggi, sedang, dan rendah berdasarkan tiap motivasi belajat tinggi, sedang, dan rendah sebagai berikut: 
Tabel 2 Persentase analisis kemampuan berpikir kreatif siswa ditinjau dari motivasi siswa

\begin{tabular}{|c|c|c|c|c|c|}
\hline No & KBK & Motivasi & Kode siswa & Jumlah & Persentase \\
\hline 1 & Tinggi & Tinggi & $\begin{array}{c}\text { S-12, S-13, } \\
\text { S-19 }\end{array}$ & 3 & $(13,63 \%)$ \\
\hline 2 & Sedang & Tinggi & $\begin{array}{c}\text { S-2, S-6, S- } \\
\text { 7, S-8, S-11, } \\
\text { S-14, S-20, } \\
\text { S-21, S-22 }\end{array}$ & 9 & $(40,9 \%)$ \\
\hline 3 & Rendah & Tinggi & $\begin{array}{c}\mathrm{S}-1, \mathrm{~S}-3, \mathrm{~S}- \\
17\end{array}$ & 3 & $(13,6 \%)$ \\
\hline 4 & Tinggi & Sedang & S-5 & 1 & $(4,55 \%)$ \\
\hline 5 & Sedang & Sedang & S-4 & 1 & $(4,55 \%)$ \\
\hline 6 & Rendah & Sedang & S-15, S-16 & 2 & $(9,09 \%)$ \\
\hline 7 & Tinggi & Rendah & 0 & 0 & $(0 \%)$ \\
\hline 8 & Sedang & Rendah & S-9, S-18 & 2 & $(9,09 \%)$ \\
\hline 9 & Rendah & Rendah & S-10 & 1 & $(4,55 \%)$ \\
\hline
\end{tabular}

2. Faktor yang mempengaruhi Kemampuan Berpikir Kreatif Matematika Siswa ditinjau dari motivasi siswa

Dari hasil wawancara yang dilakukan terhadap siswa yang terpilih dapat dianalisis faktor internal yang mempengaruhi kemampuan berpikir kreatif matematika siswa. Adapun faktor-faktor yang mempengaruhi kemampuan berpikir kreatif siswa sebagai berikut:

a. Siswa mengalami ketidakmampuan dalam mengungkapkan ide-idenya yangdimiliki untuk menyelesaikan soal yang diberikan.

b. Siswa kurang percaya diri dengan hasil jawaban sendiri.

c. Siswa kurang mampu dalam menentukan rumus yang akan digunakan.

d. Siswa sering menganggap pengecekan jawaban tidak penting karena beranggapan hasil jawaban sudah benar.

a. Kemampuan Berpikir Kreatif Siswa Ditinjau Dari Motivasi Siswa

Untuk menentukan kategori kemampuan berpikir kreatif ditinjau dari motivasi siswa digunakan angket motivasi sebanyak 30 butir pertanyaan. Setelah siswa mengerjakan angket motivasi dan dikumpulkan. Sedangkan untuk menentukan kategori kemampuan berpikir kreatif matematika siswa diperoleh data berupa hasil pekerjaan siswa kemudian dari data mentah tersebut diolah sehingga dapat dilihat pencapaian kemampuan berpikir kreatif siswa. Adapun hasil yang dicapai siswa sebagai berikut. Untuk menentukan kategori kemampuan berpikir kreatif siswa digunakan soal tes berbentuk essay sebanyak 3 soal. Setelah siswa mengerjakan soal dan dikumpulkan, soal tersebut dikoreksi dan ditabulasi. Dari hasil tabulasi diperoleh 4 siswa yang memenuhi KKM dan 18 siswa yang tidak memenuhi KKM. Berikut ini adalah hasil temuan penelitian kemampuan berpikir kreatif ditinjau dari motivasi siswa.

Sejalan dengan pendapat Rahma (2017: 33) menyatakan bahwa kriteria kemampuan berpikir kreatif matematika siswa terdiri dari tiga kriteria yaitu kriteria tinggi, sedang, dan rendah. Untuk kriteria tinggi berada pada antara lebih dari $70 \%$ sampai kurang dari sama dengan $100 \%$, kriteria sedang berada pada lebih dari $50 \%$ sampai kurang dari $70 \%$, dan untuk kriteria rendah berada pada kurang dari sama dengan 50\%. Sejalan dengan pendapat Saifudin Azwar (2013: 163) menyatakan bahwa konversi data kuantitatif ke kualitatif kriteria motivasi siswa terdiri dari tiga kriteria yaitu kateria tinggi, sedang, dan rendah. Untuk kriteria tinggi berada pada antara lebih dari 80 sampai kurang dari sama dengan 120, kriteria sedang berada pada lebih dari 40 sampai kurang dari 80, dan untuk kriteria rendah berada pada lebih dari 0 sampai kurang dari sama dengan 40 .

Berdasarkan pemaparan di atas dapat disimpulkan bahwa kemampuan berpikir kreatif siswa ditijau dari motivasi siswa. Untuk masing-masing motivasi terdapat kategori motivasi siswa tinggi, sedang, 
dan rendah. Walaupun mereka mempunyai motivasi yang beragam mereka juga mempunyai kemampuan berpikir kreatif yang beragam.

a. Faktor yang mempengaruhi Kemampuan Berpikir Kreatif Matematika Siswa

Untuk kemampuan berpikir kreatif tinggi dalam mempelajari lingkaran pada indikator berpikir lancar terdapat jawaban siswa yang diperoleh dapat diketahui bahwa siswa menjawab soal kemampuan berpikir lancar dan benar dengan berbagai jawaban berbeda. Dari hasil jawaban siswa, kebanyakan hanya menjawab soal dengan cara yang singkat tetapi menghasilakan jawaban yang benar dan ada juga jawaban yang salah dalam penyelesaian masalah matematika

Hal ini sejalan dengan pendapat Baharuddin dan Esa Nur Wahyuni. (2010: 16) secara garis besar faktor yang mempengaruhi belajar dan prestasi belajar untuk mencapai kemampuan berpikir kreatif dapat digolongkan menjadi dua bagian, yaitu faktor internal dan faktor eksternal. Berdasarkan pemaparan di atas disimpulkan bahwa faktor yang mempengaruhi kemampuan berpikir kreatif dalam memyelesaikan soal lingkaran meliputi faktor internal yaitu Siswa mengalami ketidakmampuan dalam mengungkapkan ide-idenya yang dimiliki untuk menyelesaikan soal yang diberikan.

\section{CONCLUSION AND SUGGESTION}

Kemampuan berpikir kreatif siswa ditinjau dari motivasi siswa sebagai berikut: a). Siswa yang memiliki motivasi tinggi: kemampuan berpikir kreatif tinggi dapat memberikan ide yang relevan dalam penyelesaian pemecahan masalah matematika dengan benar dan lancar, kemampuan berpikir sedang dapat memberikan ide yang relevan dalam penyelesaian pemecahan masalah meskipun pengungkapan yang diberikan kurang jelas, kemampuan berpikir kreatif rendah terdapat jawaban siswa untuk menuliskan rumus dengan kalimat yang singkat sehingga dalam mengungkapkan ide-idenya cara menyelesaikan soal yang diberikan kurang jelas. b). Siswa yang memiliki motivasi sedang: kemampuan berpikir kreatif tinggi terdapat siswa mengungkapkan ideidenya dengan cara menyelesaikan soal yang diberikan kurang jelas walaupun menuliskan rumus sudah benar, kemampuan berpikir kreatif sedang terdapat siswa kurang percaya diri dengan hasil jawaban sendiri tetapi dapat memberikan ide yang relevan dalam penyelesaian pemecahan masalah matematika dengan benar dan lancar, kemampuan berpikir kreatif rendah terdapat siswa memberikan ide yang relevan dalam penyelesaian pemecahan masalah matematika dengan benar dan lancar meskipun pengungkapan yang diberikan kurang jelas. c). Siswa yang memiliki motivasi rendah: kemampuan berpikir kreatif tinggi terdapat tidak ada siswa yang memiliki motivasi rendah dan kemampuan berpikir kreatif tinggi, kemampuan berpikir kreatif sedang terdapat siswa memberikan ide yang relevan dalam penyelesaian matematika dengan benar dan lancar meskipun pengungkapan yang diberikan kurang jelas, kemampuan berpikir kreatif rendah terdapat siswa tidak sampai membuat kesimpulan karena sudah beranggapan hasil jawaban sudah benar. Sebagaian besar ketidakmampuan siswa mencapai tahap kemampuan berpikir kreatif disebabkan oleh faktor: a) Siswa mengalami ketidakmampuan dalam mengungkapkan ide-idenya yang dimiliki untuk menyelesaikan soal yang diberikan. b) Siswa kurang percaya diri dengan hasil jawaban sendiri. c) Siswa kurang mampu dalam menentukan rumus yang akan digunakan. d) Siswa sering menganggap pengecekan jawaban tidak penting karena beranggapan hasil jawaban sudah benar.

Berdasarkan kesimpulan di atas terdapat beberapa saran yang dapat penulis sampaikan pada penelitian ini sebagai berikut:

1. Bagi Guru

Guru sebaikanya dapat meningkatkan kualitas pembelajaran dan dapat memberikan gambaran bahwa proses pembelajaran yang terjadi dalam pendidikan sehingga mampu memberikan solusi yang 
baik dalam proses pembelajaran selanjutnya dengan cara menumbuhkan kemampuan berpikir kreatif matematis pada diri siswa.

\section{Bagi Siswa}

Siswa diharapkan dapat dijadikan sebagai bahan evaluasi dan introspeksi diri dalam mengikuti proses belajar mengajar.

3. Bagi Peneliti

Peneliti diharapkan dapat digunakan sebagai bahan pertimbangan dalam mengajar, sebagai bahan masukan bahwa penting mengedepankan kemampuan berpikir kreatif matematis dalam diri siswa serta sebagai salah satu syarat dalam memenuhi gelar Sarjana Pendidikan.

4. Bagi Peneliti Lain

Peneliti lain disarankan agar dapat memberi dan menambah wawasan pengetahuan serta sebagai acuan untuk melakukan penelitian yang berkaitan dengan kemampuan berpikir kreatif matematis dalam diri siswa.

\section{REFERENCES}

Arikunto, Suharsimi. (2013). Dasar-Dasar Evaluasi Pendidikan (Edisi Kedua). Jakarta: Bumi Aksara. Arikunto, Suharsimi. (2013). Prosedur Penelitian Suatu Pendekatan Praktis. Jakarta: PT Rineka Cipta.

Azwar, Saifudin. (2013). Tes prestasi: fungsi dan pengukuran prestasi belajar. Yogyakarta: Pustaka Pelajar.

Buyung, B., \& Nirawati, R. (2018). Pengaruh Karakter Kerja Keras Terhadap Kemampuan Literasi Matematis Siswa Melalui Model Discovery Learning. JPMI (Jurnal Pendidikan Matematika Indonesia), 3(1), 21-25.

BuyungBaharuddin dan Esa Nur Wahyuni. (2010). Teori Belajar dan Pembelajaran. Yogyakarta: Ar-Ruzz Media.

Irwan. (2011). "Pengaruh Pendekatan Problem Posing Model search, Solve, Create And Share (SSCS) Dalam Upaya Meningkatkan Kemampuan Penalaran Matematis Mahasiswa Matematika". Jurnal Penelitian Pendidikan, Vol. 12 No. 1, April 2011. Universitas Negeri Padang.

Ladeni, J., Yerizon dan Nilawasti Z.A. (2012). "Meningkatkan Motivasi Belajar Matematika Siswa Dengan Penerapan Model Pembelajaran Kooperatif Tipe Think Talk Write". Jurnal Pendidikan Matematika. Volume 1 Nomor 1, 81-86.

Lampiran Peraturan Mentri Pendidikan Nasional RI No 23 Tahun 2006 dalamhhtp://staf.unila.ac.id/radengunawan/files/2011/09/Permendiknes No. 23 tahun 2006.pdf.

Nindy Citroresmi, Nurhayati. (2017). Penerapan Model Pembelajaran Means-Ends Analysis Untuk Meningkatkan Kemampuan Pemecahan Masalah Matematis Siswa. JPMI (Jurnal Pendidikan Matematika Indonesia), 2(1), 13-18.

Nurhayati, Sugiatno, \& Hamdani. (2013). Mengatasi Kesulitan Komunikasi Matematis Siswa SMA Menggunakan Wawancara Klinis Berbantuan Tablet Berbasis Multi Representasi. Jurnal Pendidikan dan Pembelajaran, Volum 2 Nomor 9, September 2013.

Nurul Husna, Nurhayati. (2018). Pengembangan Pembelajaran Scientific Berbasis Multirepresentasi Untuk Menunjang Pembelajaran Matematika Dalam Kurikulum 2013. JPMI (Jurnal Pendidikan Matematika Indonesia), 3(2), 74-80.

Nasir, M. (2016). "Analisis Kemampuan Berpikir Kreatif Berdasarkan Motivasi Siswa Dalam Menyelesaikan Soal Trigonometri Pada Siswa Kelas XI IPA Man Tlogo Blitar Tahun Ajaran 2015/2016". Skripsi, Universitas Tarbiyah dan Ilmu Keguruan Institut Agama Islam Negeri (IAIN) Tulungagung.

Rahma Faelasofi. (2017). "Identifikasi Kemampuan Berpikir Kreatif Matematika Pokok Bahasan Peluang". Jurnal Edumath, Volume 3 Nomor 2, 2017, Halaman 155-163. 
Siregar, Syofian. (2013). Metode Penelitian Kuantitatif Perhitungan Manual \& SPSS. Jakarta: Prenadamedia Group.

Siswono, T.Y.E. (2015). Model Pembelajaran Matematika Berbasis Pengajuan dan Pemecahan Masalah untuk Meningkatkan Kemampuan Berpikir Kreatif.Surabaya: Unesa Uniersity Press.

Sugiyono. (2012). Metode Penelitian dan R\&D. Bandung: Alfabeta.

Sumartono. (2015). "Motivasi Dan Hasil Belajar Siswa Dalam Pembelajaran Matematika Dengan Menggunakan Model Pembelajaran Kooperatif Tipe Scramble Di Smp”. Jurnal Pendidikan Matematika, Volume 3 Nomor 1, Halaman84 - 91. 